Article

\title{
Diameter Growth, Biological Rotation Age and Biomass of Chinese Fir in Burning and Clearing Site Preparations in Subtropical China
}

\author{
Hua Zhou, Shengwang Meng and Qijing Liu * \\ Forestry College, Beijing Forestry University, No. 35 Tsinghua East Road Haidian District, Beijing 100083, China; \\ jeamourvous@163.com (H.Z.); wangzai1220@126.com (S.M.) \\ * Correspondence: liuqijing@bjfu.edu.cn; Tel.: +86-13911806586 \\ Academic Editors: Jesus Julio Camarero, Raúl Sánchez-Salguero and Juan Carlos Linares \\ Received: 9 July 2016; Accepted: 11 August 2016; Published: 18 August 2016
}

\begin{abstract}
Sustained forest management of Cunninghamia lanceolata (Chinese fir) plantations in subtropical China is restricted by the limited availability of quantitative data. This study combines inventory data and tree-ring analysis of Chinese fir from natural and plantation forests that were subjected to controlled burning or brush clearing site preparations. Inter-annual variation of Chinese fir tree-ring widths were measured for the controlled burning, brush clearing and natural forest sites. The mean annual diametric growth of Chinese fir was $0.56 \mathrm{~cm} \cdot \mathrm{year}^{-1}$ for the natural forest, $0.80 \mathrm{~cm} \cdot$ year $^{-1}$ for the brush clearing site and $1.10 \mathrm{~cm} \cdot$ year $^{-1}$ for the controlled burning site. The time needed to reach the minimum cutting/logging diameter of $15 \mathrm{~cm}$ was 14 years in the controlled burning site, 19 years in the brush clearing site and $>40$ years in the natural forest. The biological rotation ages for the burning, cutting and natural forest sites were 15, 26 and $>100$ years, respectively. The total aboveground biomasses for the burning and clearing sites were $269.8 \mathrm{t} \cdot \mathrm{ha}^{-1}$ and $252 \mathrm{t} \cdot \mathrm{ha}^{-1}$, respectively. These results suggest that the current 25 -year cutting cycle greatly underestimates the growth rate of Chinese fir plantations.
\end{abstract}

Keywords: biomass; Chinese fir; rotation age; site preparation; subtropical forests

\section{Introduction}

Sustainable forest management is a predominant theme in natural resource management because land managers need to provide current and future generations with the products and services that they desire [1]. Intensive management through vegetation control (e.g., controlled burning and clearing ground vegetation) can substantially increase timber volumes, but it can also reduce some aspects of biological diversity [2-4]. Successful sustainable forest management requires long-term information on tree growth. Most growth data in tropical forests has been collected in permanent sample plots for fewer than 20 years [5-7]. Therefore, long-term growth changes have been evaluated using short-term data that may produce biased conclusions $[5,8]$. As a tool for sustainable forest management, tree-ring data have been widely employed to obtain and study the growth pattern, release and suppression of trees in temperate and tropical forests [9-14].

Site preparation is a very important tool in natural resource management because it promotes the early establishment and growth of crop trees by reducing competition from ground vegetation [15]. Natural resource managers have contemplated issues related to site preparation treatments. Several types of harvesting and silvicultural activities may impact plant community and biodiversity in managed forests, including the harvesting process itself, pre-harvest activities, such as pre-commercial thinning, and post-harvest site preparation activities (e.g., chemical/mechanical preparation of the site for planting) [16-19]. Various mechanical/chemical site preparation treatments are applied at 
stand initiation to reduce competing vegetation and improve crop tree growth [20]. In subtropical China, site preparation for planting Cunninghamia lanceolata (Chinese fir) mainly consists of controlled burning and brush clearing [21]. The long-term effects of brush clearing on the growth and cumulative biomass of Chinese fir are more complex than those of controlled burning. Compared to controlled burning, the effects of brush clearing are transient and the soil carbon release is significantly slow. Controlled burning can impact carbon storage and release not only during the burning process, but also during the post-burning period [22]. In our burning site, as no other seedlings or broadleaved trees were recorded, we speculate that nearly $100 \%$ of organic materials should have burnt. The long-term impacts of burning on tree growth and carbon storage have been studied, although the results are inconsistent [23-25]. These contradictory reports may be caused by differences in burning intensity, soil moisture, topography and vegetation type [26,27]. In many regions of China, most regulations for Chinese fir are based on mean growth rates from different stands and geographical areas, and most forest managers usually ignore biodiversity and growth differences of different site preparation methods, especially reforestation after logging natural forests. These forest practices are usually aimed at short-term economic and commercial feasibility, creating doubts on the long-term sustainability of forests [28,29]. Thus, appropriate site preparation management that may save manpower, costs and time is essential for the long-term sustainability of Chinese fir plantations.

The subtropical area of South China is vulnerable to climate change, and it is considered to be an important region for biodiversity and a great natural reserve for endemic plant species [30-32]. Subtropical evergreen broadleaved forests are a typical climax vegetation in the subtropical zone of South China. In past decades, large areas of natural evergreen broadleaved forests in many regions of South China might comprise secondary forests, plantations, orchards and arable land [33]. The Chinese Government has promised that the area of planted forests will increase by 40 million ha by 2020, and Chinese fir plantations might increase rapidly in this region [34]. The Chinese fir is a fast-growing tree, up to $30 \mathrm{~m}$ tall and $250 \mathrm{~cm}$ in diameter; and its wood is desired highly for many purposes, because it is easy to process, durable, hard and rot-resistant. Its range extends from southern China to the southern area of Qinling Mountain, and it extends into Vietnam. In China, Chinese fir trees have been planted for over 1000 years [35], but they are rare in primary forests because of a long history of anthropogenic influences. It is one of the most important plantation tree species in South China in terms of commercial value, and its plant area covers over 12 million ha, which accounts for approximately $6.5 \%$ of all plantation forests worldwide [36,37]. Therefore, Chinese fir forests play an important role in the accumulation of biomass carbon.

In this study, we aimed to estimate the rates of diametrical growth, as well as the biological rotation ages (BRAs) of Chinese fir trees in subtropical China using dendrochronological methods. We also performed a basic evaluation of the effects of burning and cutting site preparations on Chinese fir plantation forests 26 and 36 years, respectively, after planting, including the average trees per unit area, the average tree diameter, the diameter distribution of trees, basal area (BA) and aboveground biomass.

\section{Experimental Section}

\subsection{Study Area}

Our study area is located in the Jiulianshan region of the eastern Nanling Mountains, which is the greatest mountain range in South China and constitutes an important geographic demarcation line between the northern and southern subtropical zones of China (Figure 1). There are vast areas of primary evergreen broadleaved forests in the region, and some of them were heavily logged in the 1970s and 1980s. In 2003, a national nature reserve was established in the region, and felling was banned thereafter. The area is characterized by a typical subtropical monsoon climate (with a warm, rainy season and a cool, dry season); the dry season lasts approximately 5 months (October/November to March). The average annual precipitation at the Xiagongtang meteorological station in our study region from 1982 to 2014 was $2024.7 \mathrm{~mm}$ with over $70 \%$ of the precipitation falling from April to 
September. The mean annual temperature ranges from $24.4{ }^{\circ} \mathrm{C}$ in the warmest month (July) to $6.8^{\circ} \mathrm{C}$ in the coolest month (January). Relative humidity remains more or less constant throughout the year ( $93 \%$ in the wet season, $81 \%$ in the dry season). The soil $\mathrm{pH}$ ranges from 4.2 to 5.5 [38], and the soils are typical acid soils of subtropical or tropical moist lowlands.

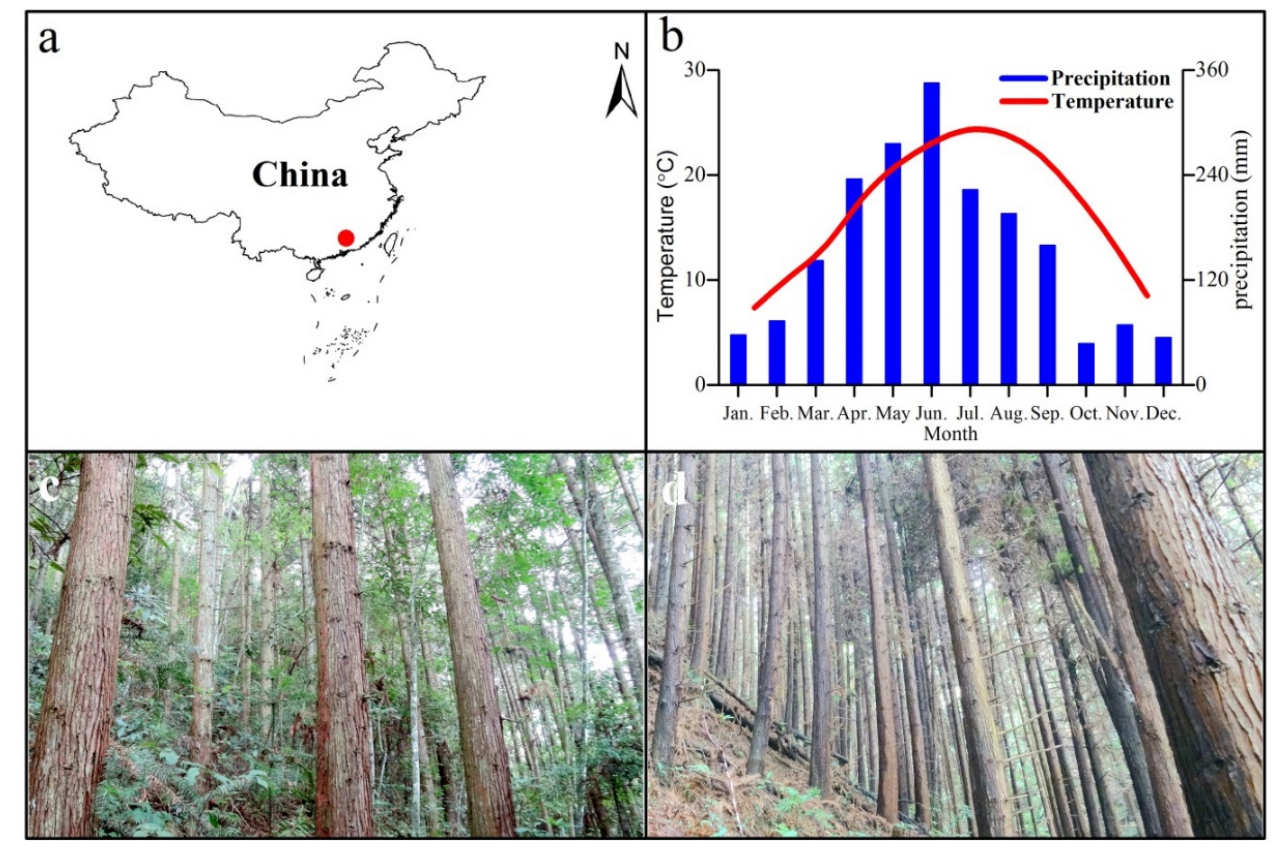

Figure 1. Study region, climate data, and forest structure. (a) The sampling site (red) in subtropical China; (b) Climate data from the Xiagongtang meteorological station from 2000 to 2014; (c) Structure of the clearing site preparation sampling site after 36 years and (d) the structure of the controlled burning site preparation sampling site after 26 years.

\subsection{Site Preparation in the Region}

This region was chosen because it represents an important part of the Chinese fir forest resource, and it contains both pure and mixed stands. Usually, there are two main site preparation methods for afforestation in the region: one is controlled burning and the other is brush clearing/cutting. To study the long-term effects of different site preparation treatments on Chinese fir, we selected two Chinese fir plantation sites, one of which was prepared by controlled burning, while the other was prepared by brush clearing. The brush clearing site was planted in the spring of 1979, and it developed into a representative mixed broadleaf-conifer forest of the subtropics, while the controlled burning site was planted in the spring of 1989, and it consists of pure Chinese fir stands (Figure 1). Forest tending methods were implement primarily between 1 and 5 years after the initial planting. The two sites, approximately $1000 \mathrm{~m}$ apart, do not differ in terms of altitude, soil type, climate or former land use.

\subsection{Experimental Design and Data Collection}

In 2015, 4-ha site preparation treatments sites were randomly selected in the study region. Two sites were planted in a checkerboard design with homogeneous cells of $3 \times 3$ trees, each of which had a $50 \mathrm{~cm} \times 50 \mathrm{~cm} \times 40 \mathrm{~cm}$ planting pit with a planting density of 2700 trees/ha and 1600 trees/ha. At each site, five randomly-located, $50 \mathrm{~m}$-long and $20 \mathrm{~m}$-wide transects were established, with each transect running perpendicularly from the valley to the upland [39]. Along each transect, one circular plot of $200 \mathrm{~m}^{2}$ was established 0-25 $\mathrm{m}$ and 25-50 m from the valley, for a total of two plots per transect and 10 plots per site. In each plot, species and diameter at breast height $(\mathrm{DBH})$ of all living trees $\geq 1 \mathrm{~cm}$ DBH were recorded. Physiographic attributes, such as slope, aspect and elevation, were recorded for each plot. Between July and August 2015, we sampled randomly 34 and 37 increment cores in each 
site. In a nearby natural forest, approximately $800 \mathrm{~m}$ from the cutting site, we collected 34 increment cores. One radial core per tree was extracted at approximately $1.0 \mathrm{~m}$ above ground level for growth analysis and age determination [40]. Because of the wet nature of the study region, wood cores were frozen for 2 weeks to prevent insect infestation [41].

\subsection{Tree-Ring Analysis}

All cores were dried, mounted and sanded with progressively finer sandpaper using standard procedures. Before measurement, all tree-ring boundaries were marked with a pencil under a stereomicroscope or magnifying glass, and they were visually cross-dated using pointer years [42]. Tree-ring width was recorded to $0.01 \mathrm{~mm}$ using the semi-automatic LINTAB 6 measuring system and the WinTSAP program [43]. The accuracy of visual cross-dating and measurement errors were further checked using the COFECHA program [44].

If the age corresponded with the planting period, tree rings were considered to be annual [45]. For each size class of a 5-cm width between 0 and $40 \mathrm{~cm} \mathrm{DBH}$, the median, minimum and maximum passage times were calculated as the number of years spent in a size class [46]. A Kruskal-Wallis test and a Dunn test were used to test for differences between the sites in the passage times for each size class. To assess the contribution of each size class to the eventual variation in ages at $30 \mathrm{~cm} \mathrm{DBH}$, we analyzed the effect of passage time in each class on age at $30 \mathrm{~cm} \mathrm{DBH}$ by a multiple regression that included all size classes, except those causing high collinearity [46].

\subsection{Analysis of Growth Changes}

Basal area growth (BAG; $\mathrm{cm}^{2} \cdot \mathrm{year}^{-1}$ ), rather than diameter growth, was used to calculate growth events, as Chinese fir has a known age trend, especially in plantations [41]. The use of BAG instead of diameter growth eliminates observing changes in growth that are caused by a negative correlation between raw ring width and tree circumference [47]. Based on the tree ring-data, current and mean annual basal area increments (CAI and MAI, respectively) were obtained using the formulae [28]:

$$
\mathrm{BACAI}_{t}=\pi\left(\mathrm{r}_{t}^{2}-\mathrm{r}_{t-1}^{2}\right)
$$

and:

$$
\mathrm{BA} \mathrm{MAI}+=\pi r_{t}^{2} / t
$$

where $r_{t}$ is the ring width in year $t$.

\subsection{Bark Thickness}

In keeping with the diameter used by the logging company, the diameter of the outside bark $\left(d_{\mathrm{ob}}\right)$ in any year was calculated from the diameter of the inside bark $\left(d_{\mathrm{ib}}\right)$ using a bark coefficient. The bark coefficient $(b)$ is defined as the diameter of the outside bark divided by the diameter of the inside bark.

The $b$ equation is:

$$
b=d_{o b} / d_{i b}=r_{o b t} / r_{i b t}
$$

where $r_{\mathrm{obt}}$ and $r_{\mathrm{ibt}}$ represent ring width with and without bark, respectively, in year $t$. Note that the bark coefficient $b$ should be the mean value of many measurements of different samples. In this study, $b$ for Chinese fir was 1.09 .

One way to arrive at the bark thickness $(B)$ of a tree in any year is to use the following equation:

$$
B_{t}=r_{t}(b-1)
$$

where $B_{\mathrm{t}}$ is the bark thickness in year $t$ and $r_{\mathrm{t}}$ is the ring width in year $t$.

Therefore, using the bark thickness of a tree in any year, we can calculate the diameter of the outside bark in any year. 


\subsection{Biomass Estimate}

The dry weight of Chinese fir in the sampling plots was calculated from previously published allometric equations [48]:

$$
W_{T}=0.096 D^{2.410}\left(n=15, R^{2}=0.99\right)
$$

where $W_{T}(\mathrm{~kg})$ is the dry weight of the total biomass of standing individuals and $D$ is the DBH $(\mathrm{cm})$. To estimate the aboveground biomass of evergreen broadleaved trees, we harvested 276 woody species through destructive sampling in a subtropical primary evergreen broadleaf forest to develop the general allometric equations for tree species group (data not shown). The regression equations for calculating the dry weight of evergreen broadleaved trees are:

$$
w_{a g b}=0.360-0.440 D+0.306 D^{2}\left(n=261, R^{2}=0.96\right)
$$

and:

$$
W_{A G B}=0.0993 D^{2.4897}\left(n=15, R^{2}=0.99\right)
$$

where $w_{a b g}(\mathrm{~kg})$ is the dry weight of individuals whose DBH was $\geq 1 \mathrm{~cm}$ and $<5 \mathrm{~cm}$, and $W_{A G B}(\mathrm{~kg})$ is the dry weight of the individuals whose $\mathrm{DBH}$ was $\geq 5 \mathrm{~cm}$ and $\leq 50.2 \mathrm{~cm} ; D$ is the DBH (cm), and $n$ represents the sample size.

\section{Results}

\subsection{Structural and Growth Characteristics of Planted and Natural Chinese Fir}

In three forest types, tree-ring analyses were completed successfully. Table 1 shows a concise summary of the growth differences between planted and natural Chinese fir. Both study sites for planted Chinese fir had normally distributed diameters (Figure 2). The mean diameter of Chinese fir trees was $18 \pm 5.2 \mathrm{~cm}$ in the burning site and $19 \pm 6.0 \mathrm{~cm}$ in the clearing site (Table 1). The average tree density of Chinese fir was $2655 \pm 442$ trees $\cdot \mathrm{ha}^{-1}$ in the burning site and $1610 \pm 477$ trees $^{\circ} \mathrm{ha}^{-1}$ in the clearing site (Table 2). More detailed structural characteristics are shown in Figure 2. In the brush clearing site, however, up to 44 woody plants (data not shown) were systematically recorded to species. Their average tree density was $2295 \pm 655$ trees $\cdot \mathrm{ha}^{-1}$ for saplings and $695 \pm 320$ trees $^{-h^{-1}}$ for broadleaved trees (Table 2).
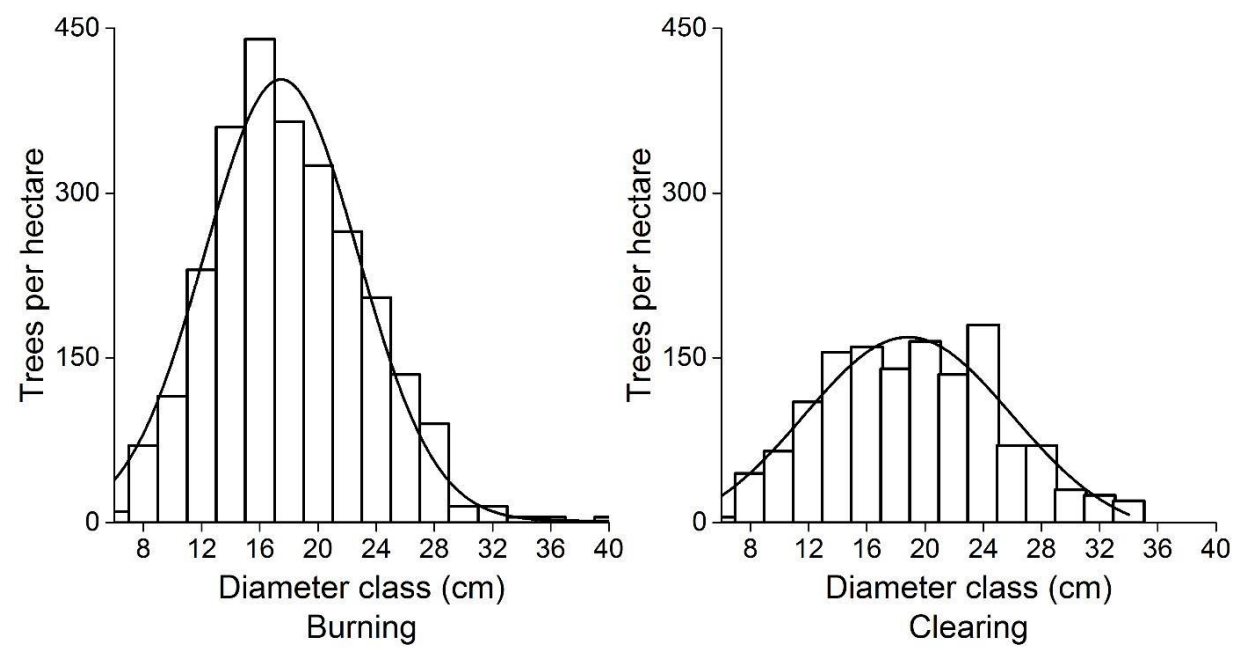

Figure 2. Trees $\cdot \mathrm{ha}^{-1}$ (only for Chinese fir) of each diameter class for the burning and clearing preparation sites. The smooth curves are Gaussian fits to the data. 
Table 1. The means of the mean annual basal area increment (MAI) and the BA-MAI for Chinese fir at different sites in the Nanling district in southern China.

\begin{tabular}{|c|c|c|c|}
\hline & \multicolumn{2}{|c|}{ Plantation } & \multirow[b]{2}{*}{$\begin{array}{l}\text { Nature Chinese } \\
\text { Fir Forest }\end{array}$} \\
\hline & $\begin{array}{l}\text { Burning Site } \\
\text { Preparation }\end{array}$ & $\begin{array}{l}\text { Clearing Site } \\
\text { Preparation }\end{array}$ & \\
\hline Latitude & $24^{\circ} 32^{\prime} 25^{\prime \prime} \mathrm{N}$ & $24^{\circ} 32^{\prime} 09^{\prime \prime} \mathrm{N}$ & $24^{\circ} 32^{\prime} 20^{\prime \prime} \mathrm{N}$ \\
\hline Longitude & $114^{\circ} 28^{\prime} 19^{\prime \prime} \mathrm{E}$ & $114^{\circ} 27^{\prime} 56^{\prime \prime} \mathrm{E}$ & $114^{\circ} 27^{\prime} 25^{\prime \prime} \mathrm{E}$ \\
\hline Altitude (m.a.s.1.) & 765 & & 793 \\
\hline Planting density (trees $\cdot \mathrm{hm}^{-2}$ ) & $2500 \sim 3000$ & $1500 \sim 2000$ & No data \\
\hline Planting pit size $(\mathrm{cm})$ & $50 \times 50 \times 40$ & $50 \times 50 \times 40$ & No data \\
\hline Slope & $<30^{\circ}$ & $<25^{\circ}$ & $<25^{\circ}$ \\
\hline Age of stand & 26 & 36 & >GREATER-80 \\
\hline Mean diameter of stand $(\mathrm{cm})$ & $18 \pm 5.2$ & $19 \pm 6.0$ & No data \\
\hline No. of increment cores & 37 & 34 & 34 \\
\hline MAI $(\mathrm{cm})$ & $1.10 \pm 0.38 \mathrm{a}$ & $0.80 \pm 0.25 b$ & $0.56 \pm 0.15 c$ \\
\hline BA-MAI $\left(\mathrm{cm}^{2} \cdot\right.$ year $\left.^{-1}\right)$ & $4.28 \pm 1.37 a$ & $3.03 \pm 0.95 b$ & $2.24 \pm 0.95 c$ \\
\hline Biological rotation age (BRA, year) & 15 & 26 & >GREATER-100 \\
\hline Diameter at BRA $(\mathrm{cm})$ & 19 & 23 & >GREATER-50 \\
\hline \multicolumn{4}{|c|}{ Local management guides for cutting cycle and minimum cutting diameter } \\
\hline Cutting cycle (CC, year) & \multirow{2}{*}{$\begin{array}{l}25 \\
15\end{array}$} & 25 & No data \\
\hline Minimum cutting diameter $(\mathrm{MCD}, \mathrm{cm})$ & & 15 & No data \\
\hline $\begin{array}{l}\text { Different letters }(a, b \text { and } c) \text { indicate statistical } \\
\text { of selected trees and the biological rotation } \\
\text { sampling sites (different site preparation: bu }\end{array}$ & $\begin{array}{l}\text { ly significant } d \\
\text { age (BRA) (ye } \\
\text { rning, cutting }\end{array}$ & $\begin{array}{l}\text { at a confidence } \\
\text { r Chinese fir ar } \\
\text { l) in the study }\end{array}$ & $\begin{array}{l}\text { f } 0.05 \text {. The number } \\
\text { cated for the three }\end{array}$ \\
\hline $\begin{array}{l}\text { Table 2. Trees } \cdot \text { ha }^{-1} \text { and total biomass } \mathrm{f} \\
\text { preparation sites. }\end{array}$ & Chinese fir & ntrolled bu & d brush clearing \\
\hline Stand Characteristics & Burning $S$ & aration & ng Site Preparation \\
\hline Chinese fir biomass (ton $\cdot \mathrm{hm}^{-2}$ ) & & & 163.4 \\
\hline Sapling biomass (ton $\cdot \mathrm{hm}^{-2}$ ) & & & 3.9 \\
\hline Broad leaved trees biomass (ton $\cdot \mathrm{hm}^{-2}$ ) & & & 84.7 \\
\hline Total biomass $\left(\right.$ ton $\cdot \mathrm{hm}^{-2}$ ) & & & 252.0 \\
\hline Chinese fir density (trees $\cdot \mathrm{hm}^{-2}$ ) & 265 & & $1610 \pm 477$ \\
\hline Sapling density (trees $\left.\cdot \mathrm{hm}^{-2}\right)(1-5 \mathrm{~cm} \cdot \mathrm{dbh})$ & & & $2295 \pm 655$ \\
\hline other tree density $\left(\right.$ trees $\left.\cdot \mathrm{hm}^{-2}\right)(>5 \mathrm{~cm} \cdot \mathrm{dbh})$ & & & $695 \pm 320$ \\
\hline Total trees per hectare $(>5 \mathrm{~cm} \cdot \mathrm{dbh})$ & 265 & & $2305 \pm 539$ \\
\hline
\end{tabular}

The diameter growth varied considerably between study sites. The individual diameter growth curves showed that the change in growth was very clear among the three study sites (Figure 3 ). The mean diameter growth varied from $0.56 \mathrm{~cm} \cdot$ year $^{-1}$ for the natural site to $1.10 \mathrm{~cm} \cdot$ year $^{-1}$ for the cutting sites. In the controlled burning and brush clearing preparation sites, the mean diameter growth exhibited similar variations. During the first 10 years of growth, relatively rapid growth occurred in the two planted Chinese fir forests based on the individual diameter growth. After 10 years of growth, the diameter growth stabilized at approximately 40 years in the clearing site. In the natural Chinese fir forest, however, the diameter growth exhibited a slow variation for approximately 100 years.

Comparing the mean diameter growth of the three forest types, the Chinese fir trees planted in the burning preparation site grew significantly faster than those planted in the clearing preparation site and those in the natural site (Table 2 and Figure 3). However, until approximately 20 years of age, tree growth seemed to be high and similar in the burning and clearing sites, although it was significantly higher than in the natural site (Figure 3). For the Chinese fir from the three study sites, the diameters at the BRA ranged from $19 \mathrm{~cm}$ for the burning site to $>45 \mathrm{~cm}$ for the natural site (Table 1). 

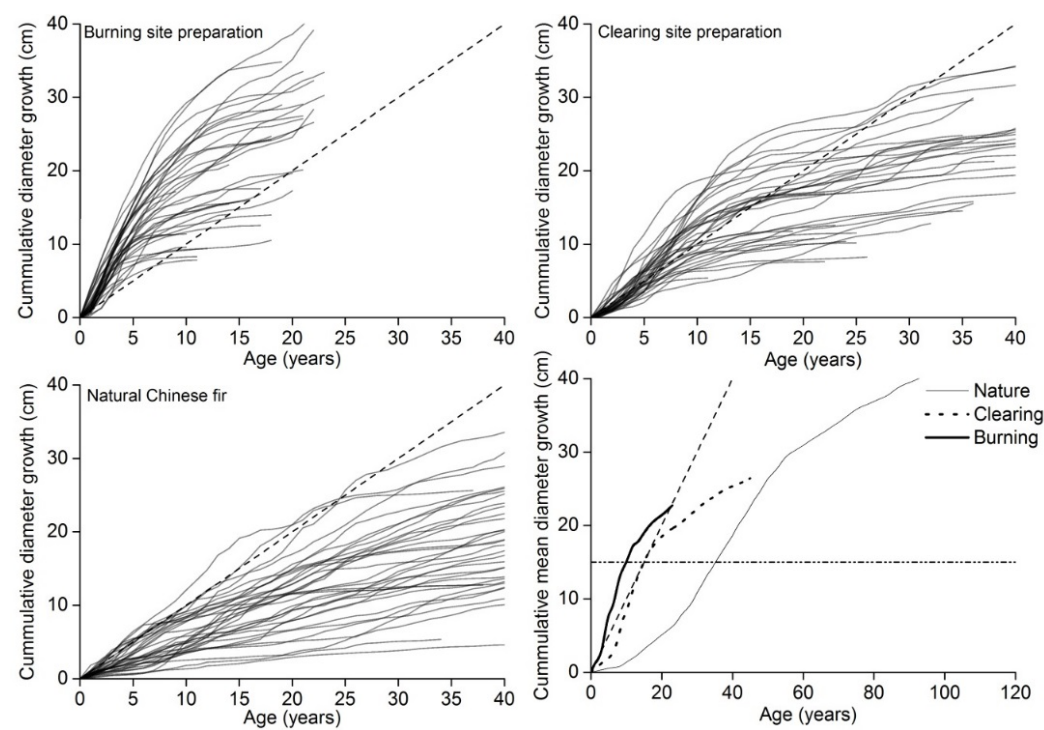

Figure 3. Individual diameter growth curves of Chinese fir at the three study areas. Mean diameter growth curves for the natural Chinese fir forest (solid line), the planted Chinese fir forest of the burning site (bold solid line) and the planted Chinese fir of the clearing site (dotted line). Dashed lines indicate a constant diameter growth of $1 \mathrm{~cm}$ per year. The dashed-dotted line represents the MCD. Note that individual diameter growth curves for the natural Chinese fir were truncated at $40 \mathrm{~cm}$ in the natural forest.

\subsection{BRAs}

Based on the BAIs, we estimated that the average BRAs for the burning and cutting sites were 15 and 26 years, respectively (Table 1 and Figure 4). For the natural site, there was not a clear reduction in the number of trees over 80 years, which may prevent a precise determination of its BRA. However, we suggest that the mean BRAs are greater than 100 years, according to the trends in the CAI and MAI (Table 1 and Figure 4).
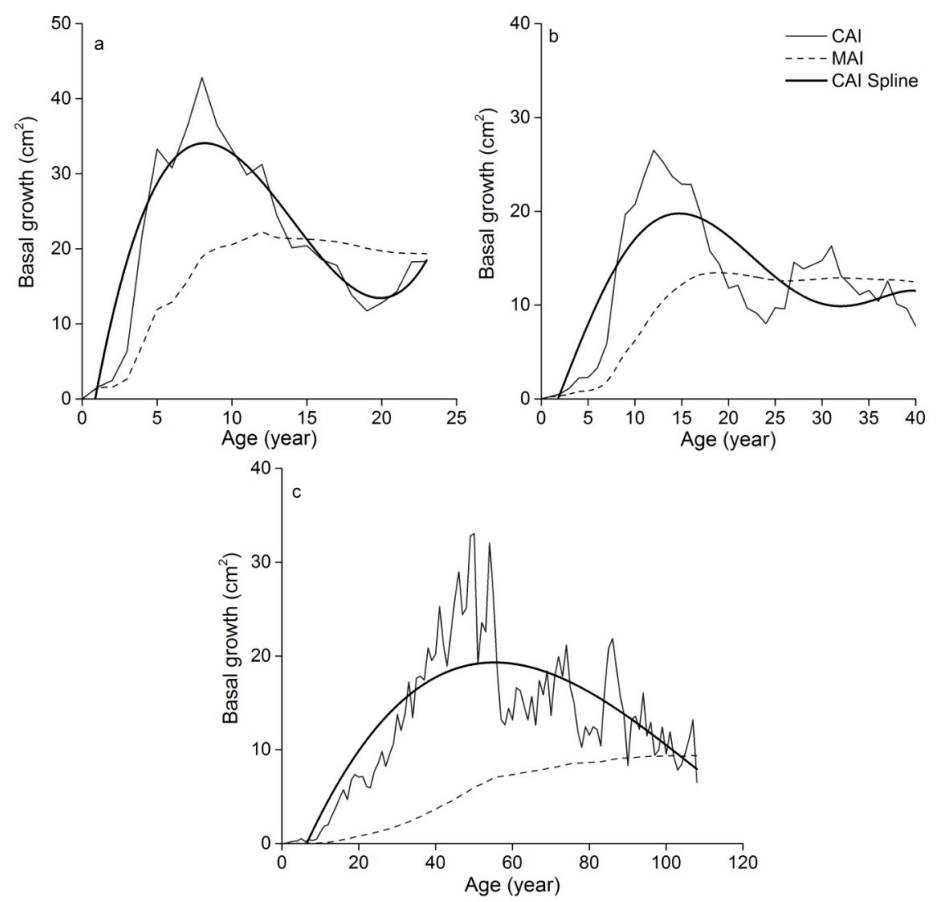

Figure 4. Current (CAI) and mean (MAI) annual basal area increments in relation to tree ages for the Chinese fir in the burning (a); clearing (b) and natural forest (c). 
In contrast to other types of site preparation, the growth rate of Chinese fir in the controlled burning site during the juvenile stages was significantly high, with an average increment of $1.5 \mathrm{~cm} \cdot$ year $^{-1}$. Annual increments increased dramatically at approximately 12 years and declined slightly at ages over 20 years. For the brush clearing site, the growth rate during the juvenile stage was relatively slow compared to that of the burning site. In the planted sites, the MAI was $3.03 \mathrm{~cm}^{2}$ for the brush clearing site and $4.28 \mathrm{~cm}^{2}$ for the controlled burning site. In the natural site, the MAI of Chinese fir was $2.24 \mathrm{~cm}^{2}$ (Table 2 and Figure 4).

\subsection{Biomass}

A concise summary of the biomass at the two planted sites is shown in Table 2. Based on the allometric equations for biomass, we estimated that the total aboveground biomasses for the burning and clearing sites were $269.8 \mathrm{t} \cdot \mathrm{ha}^{-1}$ and $252 \mathrm{t} \cdot \mathrm{ha}^{-1}$, respectively. The diameter classes of the two sites were normally distributed (Figure 5). In the burning site, the biomass for diameters ranging from $12 \mathrm{~cm}$ to $28 \mathrm{~cm}$ was $253.8 \mathrm{t} \cdot \mathrm{ha}^{-1}$, which accounted for over $90 \%$ of the total aboveground biomass. In the clearing site, the biomasses of Chinese fir, saplings and broadleaved trees were $163.4 \mathrm{t} \cdot \mathrm{ha}^{-1}$, $3.9 \mathrm{t} \cdot \mathrm{ha}^{-1}$ and $84.7 \mathrm{t} \cdot \mathrm{ha}^{-1}$, respectively.
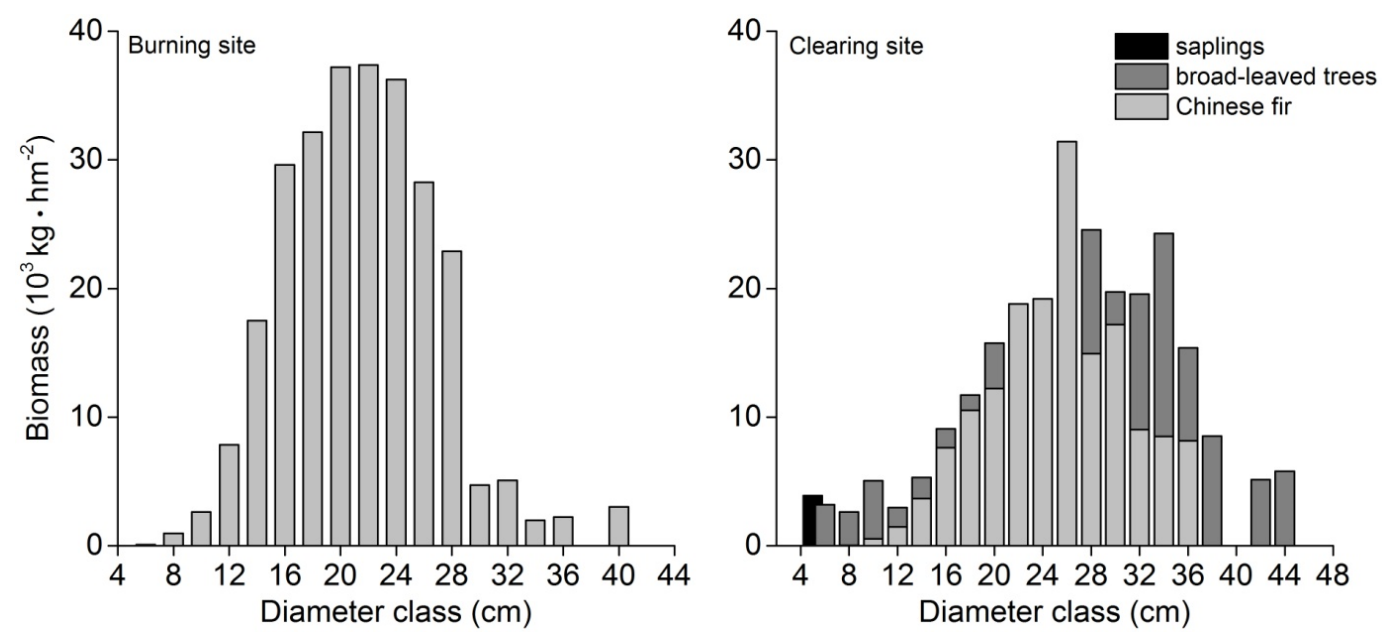

Figure 5. Biomass distribution of each diameter class for the controlled burning and brush clearing sites.

The distribution ratio of the aboveground biomass per tree diameter class recorded at each site exhibited a normal distribution (Figure 6a). Therefore, for the burning site, the maximum value of the aboveground biomass was obtained for the $22 \mathrm{~cm}$-diameter class. The maximum value of the aboveground biomass at the clearing site was obtained for $26 \mathrm{~cm}$-diameter class. In the cutting site, however, two separate groups were observed (Figure 6b): broadleaved trees with diameters smaller than $20 \mathrm{~cm}$ or larger than $30 \mathrm{~cm}$. The smaller diameter trees accounted for $9.3 \%$ of the total biomass of the clearing site, while larger diameter trees accounted for $25.8 \%$ of the total biomass of the clearing site. However, it was observed that the trees $\cdot \mathrm{ha}^{-1}$ of the smaller diameter trees were higher than those of the larger diameter trees (Table 2). 

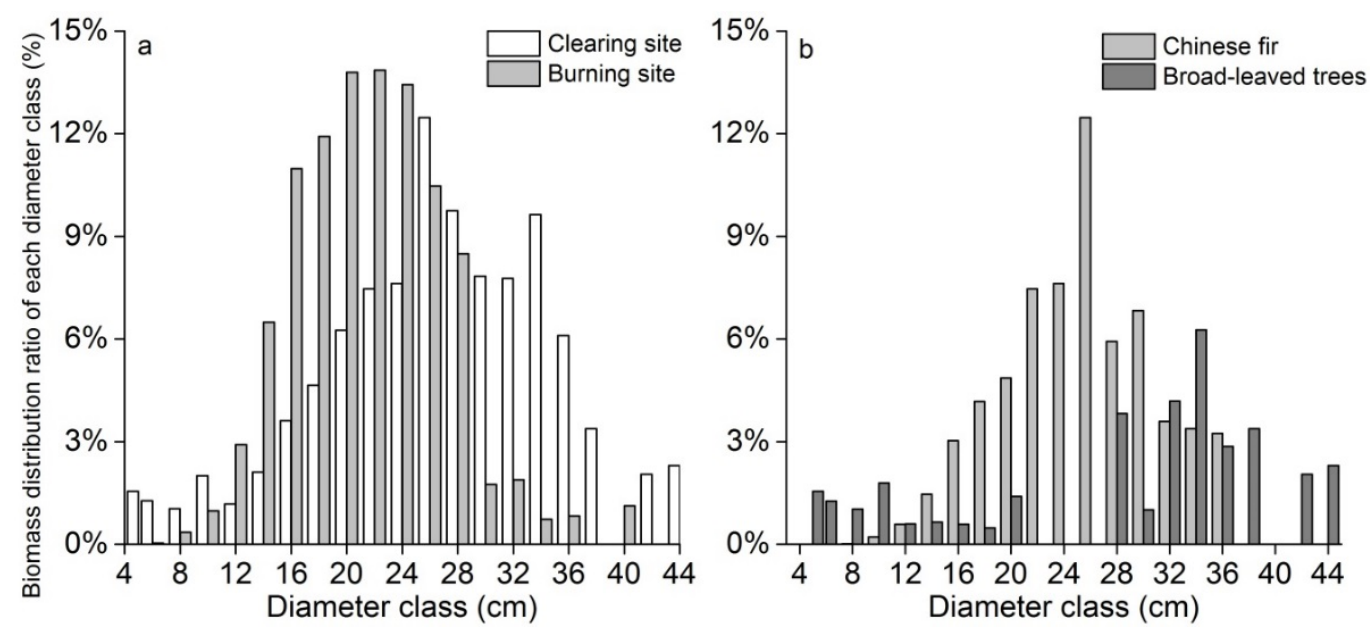

Figure 6. The biomass distribution ratio of each diameter class in the controlled burning and brush clearing sites (a) and the biomass distribution ratio of each diameter class of Chinese fir and broadleaved trees in the brush clearing site $(\mathbf{b})$.

\section{Discussion}

\subsection{Evaluation of the Mean Diameter and BRA}

Long-term growth data would be indispensable for sustainable forest management and planning [49]. However, in the long term, such information might not have been sufficiently assessed through detailed surveys. In the present study, we observed differences in Chinese fir tree growth rates between the three sites. The planted Chinese fir MAI was $1.1 \mathrm{~cm} \cdot \mathrm{year}^{-1}$ and $0.80 \mathrm{~cm} \cdot \mathrm{year}^{-1}$ for the burning and clearing sites, respectively, but it only $0.56 \mathrm{~cm} \cdot \mathrm{year}^{-1}$ for the natural site. Based on these rates, Chinese fir trees in the clearing site would increase to $15 \mathrm{~cm} \mathrm{DBH}$ during the first 20 years of growth, whereas Chinese fir trees in the burning site would increase to $22 \mathrm{~cm} \mathrm{DBH}$ in the same time frame. Our growth rates are slightly higher than previous estimates for Chinese fir in the same district [50-52]. For example, Cai et al. reported a MAI of $0.81 \mathrm{~cm} \cdot$ year $^{-1}$ and a CAI of $0.90 \mathrm{~cm} \cdot \mathrm{year}^{-1}$ for planted Chinese fir in the first 10 years. The reason for this variation might be partly due to several factors, including site preparation, site differences or planting density. To the best of our knowledge, there is no study of the growth rate of planted Chinese fir in our study region, which prevented a comparison of growth rates.

In the natural site, Chinese fir trees needed over 100 years to reach the BRA (Table 1 and Figure 4). However, the Chinese fir trees in the clearing site, in which the environmental conditions are probably very similar to those of natural forests several decades previously, required only 26 years to the BRA. This implies that the Chinese fir trees in the brush clearing site required 18 years to reach the MCD established by the local forest regulations. Some local studies of planted Chinese fir forests indicated that the cutting cycles (CCs) ranged from 18-26 years based on technical maturity, economic maturity and quantitative maturity [52,53]. This corresponds with our results. However, the 25-year CC for the burning site was significantly longer than the BRA (Table 1 and Figure 4). Meanwhile, over 30 years should be taken to enhance the proportion of large-diameter trees on high-quality forest land [52]. The proportion of Chinese fir trees that had a DBH $>20 \mathrm{~cm} 36$ years after planting was $50.3 \%$ in the clearing site, whereas the same proportion at the burning site 26 years after planting was $40.3 \%$. Several studies indicated that tree growth releases mostly take place during the juvenile phase because of competition for light $[9,54]$. In the clearing site, the Chinese fir trees were the dominant trees because they outcompeted other trees for light. This implies that the growth of Chinese fir in the burning site would be suppressed, while the growth of Chinese fir in the clearing site would be released, in the following decade. A similar study in a nearby district also indicated that ecological 
thinning and cutting significantly increased DBH and individual growth volume [55]. Recent studies also suggested that forest management should be adapted to reduce competition for resources within stands to enhance tree growth [56-58]. In addition, as one of the most important concepts of sustained management, the MCD can be calculated according to a dendrochronological analysis of tree growth. Although most studies in the tropics or subtropics mainly focus on a volume-based MCD [52,53,59-61], the MCD can also be calculated from BAIs [62-64]. However, the use of volume-based CAI and MAI is often constrained by height measurements and the existence of significant age-diameter and diameter-height relationships, as reported by Schöngart [61]. Generally speaking, the MCD or BRAs determined by BA are lower than those that are determined by volume, although there are only slight differences in the shapes of the CAI and MAI curves. From a forest regeneration viewpoint, the MCD and the associated BRA should also consider tree physiology [65]. This implies that the BRA should be larger than the fructification ages. Many studies of tropical species suggested that logging ages should be four to five times longer than currently practiced $[61,66]$. However, it is unclear whether $\mathrm{MCD} / \mathrm{BRA}$ based on volume or BA is a better choice. By graphing the CAI and BA MAI curves, the point at which they intersect is considered by many landowners to be representative of the BRA for the stand. We estimated that the BRAs of the burning, clearing and natural sites were 15, 26 and $>100$ years, respectively. Our results showed that to reach an MCD of $15 \mathrm{~cm}$, the planted Chinese fir trees in the burning and clearing sites required 14 and 19 years, respectively. These data indicate that CCs for planted Chinese fir are shorter than those currently practiced by local logging companies or the government. This implies that the current 25 -year CC established by the local forestry administration is significantly longer than the BRA of the burning site. Without a doubt, the brush clearing site preparation delayed the cutting rotation age, which will aid the preservation of the structure and composition of natural forests as sources of wood and biological diversity.

\subsection{Evaluation of the Aboveground Biomass}

The total aboveground biomass was $269.8 \mathrm{t} \cdot \mathrm{ha}^{-1}$ in the burning site and $252 \mathrm{t} \cdot \mathrm{ha} \mathrm{a}^{-1}$ in the clearing site (Table 2). As a result, the total biomass in the clearing site was slightly lower than that in the burning site. This may be due to the juvenile tending during the first five years after planting Chinese fir, in which all other seedlings or saplings were cleared. This also explains the small numbers of broadleaved trees from $20-28 \mathrm{~cm} \mathrm{DBH}$ in the clearing site (Figure $6 \mathrm{~b}$ ). Another reason may be the enhanced stand density values of the burning site, which contained $39.4 \%$ more crop trees $\cdot \mathrm{ha}^{-1}$ than the brush clearing site. Many previous studies indicated that transformation of broadleaved forests to pure Chinese fir plantations would decrease biomass/carbon storage and the production of the first rotation $[33,35,67]$. This is not consistent with our results. Chinese fir plantations' biomass, nutrient accumulation and allocation have also been studied, although the results have been mixed. For example, Yang et al. [68] reported that stand age was the main factor affecting biomass and nutrient accumulation and allocation, and different organs had significant differences in their biomass and nutrient storage. Yu et al. [69] reported that a 32-year-old Chinese fir plantation had a medium-to-high level of total biomass. In contrast, $\mathrm{Wu}$ et al. [70] found that crop tree release in a Chinese fir plantation not only promoted stand growth, but also optimized stand structure, which enabled crop trees to sustain rapid growth and reach larger diameters. Site preparation for reforestation or afforestation is difficult to implement accurately, although it is easier if topography does not vary greatly. However, the benefits of site preparation appear to be more obvious in the early years of growth, and they often decrease over time, with growth rates coinciding with non-prepared sites by the end of the rotation [71,72]. Furthermore, site preparation by controlled burning could significantly reduce biodiversity, which might make crop trees more vulnerable to particular pests and diseases. A recent study indicated that minimizing the disturbance of site preparation would mitigate soil carbon release [21]; thus using brush clearing site preparation would be more practical and a good choice for site preparation based on stand biomass estimates. 


\section{Conclusions}

This study described the main growth characteristics of Chinese fir at a burning preparation site, a clearing preparation site and a natural forest, and therefore, it considered the different site preparations for planting Chinese fir in subtropical China. A tree-ring analysis, as well as a biomass evaluation, is a valuable tool for managing natural and planted forests [54]. Inter-annual changes in tree-ring widths were measured using tree rings of Chinese fir trees from the burning, clearing and natural sites. Chinese fir trees showed similar patterns of growth responsiveness to controlled burning and clearing site preparations at the plot and tree scales, but they grew significantly slower in the natural site. A comparison of the growth variation and the total aboveground biomass, which incorporated plot survey data and tree ring data, showed significant differences in density, average DBH, BA, biomass and BRA between Chinese fir populations at the various site. The controlled burning site offered more favorable environmental conditions for the early development of Chinese fir, and the brush clearing site offered suitable natural conditions for the long-term development of Chinese fir and natural forests. In conclusion, these results are a useful source of information for the sustainable management and planning of Chinese fir plantation, such as those occurring in subtropical China.

Acknowledgments: This study was financially supported by the National Hi-tech Research and Development Plan (Grant No. 2013AA122003). Field work was aided by the Administration Bureau of Jiulian Mountain National Nature Reserve, which granted us permission to conduct surveys and samplings in the forest. We thank Zhong Hao, Zhong Yuanchang, Liang Yuelong, Hu Hualin and Fu Qinglin for providing logistical support. This manuscript was improved by the anonymous reviewers.

Author Contributions: Hua Zhou wrote the manuscript. All authors contributed to study design and manuscript editing, and Qijing Liu conducted the analyses.

Conflicts of Interest: The authors declare no conflict of interest.

\section{References}

1. Sample, V.A. Sustainability in Forestry: Origins, Evolution and Prospects; Pinchot Institute for Conservation: Washington, DC, USA, 2004.

2. Borders, B.; Bailey, R. Loblolly pine-Pushing the limits of growth. South. J. Appl. For. 2001, 25, 69-74.

3. Jones, P.D.; Edwards, S.L.; Demarais, S.; Ezell, A.W. Vegetation community responses to different establishment regimes in loblolly pine (Pinus taeda) plantations in southern Mississippi, USA. For. Ecol. Manag. 2009, 257, 553-560. [CrossRef]

4. Zutter, B.; Miller, J. Eleventh-year response of loblolly pine and competing vegetation to woody and herbaceous plant control on a Georgia flatwoods site. South. J. Appl. For. 1998, 22, 88-95.

5. Clark, D.A.; Clark, D.B. Life-history diversity of canopy and emergent trees in a neotropical rain-forest. Ecol. Monogr. 1992, 62, 315-344. [CrossRef]

6. Clark, D.A.; Clark, D.B. Getting to the canopy: Tree height growth in a neotropical rain forest. Ecology 2001, 82, 1460-1472. [CrossRef]

7. Condit, R. Research in large, long-term tropical forest plots. Trends Ecol. Evolut. 1995, 10, 18-22. [CrossRef]

8. Lieberman, D.; Lieberman, M.; Hartshorn, G.S.; Peralta, R. Growth rates and age-size relationships of tropical wet forest trees in Costa Rica. J. Tropical Ecol. 1985, 1, 97-109. [CrossRef]

9. Brienen, J.W.; Zuidema, P.A. Lifetime growth patterns and ages of Bolivian rain forest trees obtained by tree ring analysis. J. Ecol. 2006, 94, 481-493. [CrossRef]

10. Canham, C.D. Suppression and release during canopy recruitment in Acer saccharum. Bull. Torrey Bot. Club 1985, 112, 134-145. [CrossRef]

11. Landis, R.M.; Peart, D.R. Early performance predicts canopy attainment across life histories in subalpine forest trees. Ecology 2005, 86, 63-72. [CrossRef]

12. Lorimer, C.G.; Frelich, L.E. A methodology for estimating canopy disturbance frequency and intensity in dense temperate forests. Can. J. For. 1989, 19, 651-663. [CrossRef]

13. Lusk, C.H.; Smith, B. Life history differences and tree species coexistence in an old-growth New Zealand rain forest. Ecology 1998, 79, 795-806. [CrossRef] 
14. Nowacki, G.J.; Abrams, M.D. Radial-growth averaging criteria for reconstructing disturbance histories from presettlement-origin oaks. Ecol. Monogr. 1997, 67, 225-249. [CrossRef]

15. Karlsson, A. Site preparation of abandoned fields and early establishment of planted small-sized seedlings of silver birch. New For. 2002, 23, 159-175. [CrossRef]

16. Lane, V.R.; Miller, K.V.; Castleberry, S.B.; Miller, D.A.; Wigley, T.B.; Marsh, G.M.; Mihalco, R.L. Plant community responses to a gradient of site preparation intensities in pine plantations in the Coastal Plain of North Carolina. For. Ecol. Manag. 2011, 262, 370-378. [CrossRef]

17. Miller, D.A.; Chamberlain, M.J. Plant community response to burning and herbicide site preparation in eastern Louisiana, USA. For. Ecol. Manag. 2008, 255, 774-780. [CrossRef]

18. Thornton, D.H.; Wirsing, A.J.; Roth, J.D.; Murray, D.L. Complex effects of site preparation and harvest on snowshoe hare abundance across a patchy forest landscape. For. Ecol. Manag. 2012, 280, 132-139. [CrossRef]

19. Yildiz, O.; Esen, D.; Karaoz, O.M.; Sarginci, M.; Toprak, B.; Soysal, Y. Effects of different site preparation methods on soil carbon and nutrient removal from Eastern beech regeneration sites in Turkey's Black Sea region. Appl. Soil Ecol. 2010, 45, 49-55. [CrossRef]

20. Miller, D.A.; Wigley, T.B.; Miller, K.V. Managed Forests and Conservation of Terrestrial Biodiversity in the Southern United States. J. For. 2009, 107, 197-203.

21. Wang, J.L.; Wang, H.M.; Fu, X.L.; Xu, M.; Wang, Y. Effects of site preparation treatments before afforestation on soil carbon release. For. Ecol. Manag. 2016, 361, 277-285. [CrossRef]

22. Fernández, I.; Cabaneiro, A.; Carballas, T. Carbon mineralization dynamics in soils after wildfires in two Galician forests. Soil Bio. Biochem. 1999, 31, 1853-1865. [CrossRef]

23. Phillips, R.L.; Zak, D.R.; Holmes, W.E.; White, D.C. Microbial community composition and function beneath temperate trees exposed to elevated atmospheric carbon dioxide and ozone. Oecologia 2002, 131, 236-244.

24. Hubbard, R.M.; Vose, J.M.; Clinton, B.D.; Elliott, K.J.; Knoepp, J.D. Stand restoration burning in oak-pine forests in the southern Appalachians effects on aboveground biomass and carbon and nitrogen cycling. For. Ecol. Manag. 2004, 190, 311-321. [CrossRef]

25. Wüthrich, C.; Schaub, D.; Weber, M.; Marxer, P.; Conedera, M. Soil respiration and soil microbial biomass after fire in a sweet chestnut forest in southern Switzerland. Catena 2002, 48, 201-215. [CrossRef]

26. Boerner, R.E.J.; Decker, K.L.M.; Sutherland, E.K. Prescribed burning effects on soil enzyme activity in a southern Ohio hardwood forest: A landscape-scale analysis. Soil Biol. Biochem. 2000, 32, 899-908. [CrossRef]

27. McCarthy, D.R.; Brown, K.J. Soil respiration responses to topography, canopy cover, and prescribed burning in an oak-hickory forest in southeastern Ohio. For. Ecol. Manag. 2006, 237, 94-102. [CrossRef]

28. López, L.; Villalba, R.; Bravo, F. Cumulative diameter growth and biological rotation age for seven tree species in the Cerrado biogeographical province of Bolivia. For. Ecol. Manag. 2013, 292, 49-55. [CrossRef]

29. Campos, J.J.; Finegan, B.; Villalobos, R. Diversified forest management: Improvement of goods and services from the biodiversity of a neotropical forest. Revista For. Centroamericana 2001, 36, 6-13.

30. Ni, J. Impacts of climate change on Chinese ecosystems, key vulnerable regions and potential thresholds. Reg. Environ. Chang. 2011, 11, 49-64. [CrossRef]

31. Wu, Z.Y. Vegetation of China; Science Press: Beijing, China, 1980; p. 825.

32. Xu, Y.; Shen, Z.H.; Ying, L.X.; Ciais, P.; Liu, H.Y.; Piao, S.L.; Wen, C.; Jiang, Y.X. The exposure, sensitivity and vulnerability of natural vegetationin China to climate thermal variability (1901-2013): An indicator-based approach. Ecol. Indic. 2016, 63, 258-272. [CrossRef]

33. Sheng, H.; Yang, Y.S.; Yang, Z.J.; Chen, G.S.; Xie, J.S.; Guo, J.F.; Zou, S.Q. The dynamic response of soil respiration to land-use changes in subtropical China. Glob. Chang. Biol. 2010, 16, 1107-1121. [CrossRef]

34. Xu, J. China's new forests aren't as green as they seem. Nature 2011, 477, 370. [CrossRef] [PubMed]

35. Chen, G.S.; Yang, Z.J.; Gao, R.; Xie, J.S.; Guo, J.F.; Huang, Z.Q.; Yang, Y.S. Carbon storage in a chronosequence of Chinese fir plantations in southern China. For. Ecol. Manag. 2013, 300, 68-76. [CrossRef]

36. FAO. Global Forest Resource Assessment 2005. Available online: ftp://ftp.fao.org/docrep/fao/008/A0400E/ A0400E00.pdf (accessed on 12 August 2015).

37. West, P.W. Growing Plantation Forests; Springer-Verlag Berlin Heidelberg: Berlin, Germany, 2006.

38. Liu, X.Z.; Xiao, Z.Y.; Ma, J.H. Scientific Survey and Study on the Forest Ecosystem in Jiangxi Nature Reserve; China Forestry Publishing House: Beijing, China, 2002; pp. 14-53.

39. MacDonald, R.L.; Chen, H.Y.H.; Palik, B.P.; Prepas, E.E. Influence of harvesting on understory vegetation along a boreal riparian-upland gradient. For. Ecol. Manag. 2014, 312, 138-147. [CrossRef] 
40. Primicia, I.; Camarero, J.J.; Janda, P.; Cada, V.; Morrissey, R.C.; Trotsiuk, V.; Bace, R.; Teodosiu, M.; Svoboda, M. Age, competition, disturbance and elevation effects on tree and stand growth response of primary Picea abies forest to climate. For. Ecol. Manag. 2015, 354,77-86. [CrossRef]

41. De Ridder, M.; Trouet, V.; Van den Bulcke, J.; Hubau, W.; Van Acker, J.; Beeckman, H. A tree-ring based comparison of Terminalia superba climate-growth relationships in West and Central Africa. Trees 2013, 27, 1225-1238. [CrossRef]

42. Yamaguchi, D.K. A simple method for cross-dating increment cores from living trees. Can. J. For. Res. 1991, 21, 414-416. [CrossRef]

43. Grissino-Mayer, H.D. Evaluating crossdating accuracy: A manual and tutorial for the computer program COFECHA. Tree-ring Res. 2001, 57, 205-221.

44. Holmes, R.L. Computer-assisted quality control in tree-ring dating and measurement. Tree-Ring Bull. 1983, 44, 69-75.

45. Stahle, D.W.; Mushove, P.T.; Cleaveland, M.K.; Roig, F.; Haynes, G.A. Management implications of annual growth rings in Pterocarpus angolensis from Zimbabwe. For. Ecol. Manag. 1999, 124, 217-229. [CrossRef]

46. Brienen, J.W.; Zuidema, P.A.; During, H.J. Autocorrelated growth of tropical forest trees: Unraveling patterns and quantifying consequences. For. Ecol. Manag. 2006, 237, 179-190. [CrossRef]

47. Biondi, F.; Qeadan, F. A theory-driven approach to tree-tring standardization: Defining the biological trend from expected basal area increment. Tree Ring Res. 2008, 64, 81-96. [CrossRef]

48. Wang, Z.C.; Du, H.; Song, T.Q.; Peng, W.X.; Zeng, F.P.; Zeng, Z.X.; Zhang, H. Allometric models of major tree species and forest biomass in Guangxi. Acta Ecol. Sinica 2015, 35, 4462-4472.

49. Therrell, M.D.; Stahle, D.W.; Mukelabai, M.M.; Shugart, H.H. Age, and radial growth dynamics of Pterocarpus angolensis in southern Africa. For. Ecol. Manag. 2007, 244, 24-31. [CrossRef]

50. Cai, C.; Qiu, S.; Cai, S. A preliminary study on shortening rotation age of Chinese fir plantation. South China For. Sci. 1993, 2, 27-30. (In Chinese)

51. Yang, Y.; He, Z.; Qiu, R.; Yu, X.; Huang, B. Growth pattern of 29-year-old Chinese fir grown from seed in different rotations. Sci. Silvae Sinicae 1999, 35, 32-36. (In Chinese)

52. Zhang, Z.; Cai, X.; Zhu, B. Study on the fixing of cutting age of the Chinese fir man-made forest. Acta Agric. Univ. Jiangxiensis 1992, 6, 46-51. (In Chinese)

53. Jie, J.; Zhan, Y.; Wu, K. Study on propor rotation period for artificial stands of Cunninghamia lanceolata in Jiangxi province. South China For. Sci. 2000, 6, 4-8. (In Chinese)

54. De Ridder, M.; Van den Bulcke, J.; Van Acker, J.; Beeckman, H. Tree-ring analysis of an African long-lived pioneer species as a tool for sustainable forest management. For. Ecol. Manag. 2013, 304, 417-426. [CrossRef]

55. Pan, J.; Zheng, L.; Chen, H.; Ye, H.; Wu, L. Growth with intermediate cuttings in mature Chinese fir plantations. J. Zhejiang A F Univ. 2014, 31, 291-295. (In Chinese)

56. Hemery, G.E. Forest management and silvicultural responses to projected climate change impacts on European broadleaved trees and forests. Intern. For. Rev. 2008, 10, 591-607. [CrossRef]

57. Way, D.A.; Oren, R. Differential responses to changes in growth temperature between trees from different functional groups and biomes: A review and synthesis of data. Tree Physiol. 2010, 30, 669-688. [CrossRef] [PubMed]

58. Doley, D. The response of forests to climate change: The role of silviculture in conserving threatened species. Aust. For. 2010, 73, 115-125. [CrossRef]

59. Leoni, J.M.; Da Fonseca Junior, S.F.; Sch Ngart, J. Growth and population structure of the tree species Malouetia tamaquarina (Aubl.) (Apocynaceae) in the central Amazonian floodplain forests and their implication for management. For. Ecol. Manag. 2011, 29, 597-611. [CrossRef]

60. Nebel, G.; Dragsted, J.; Simonsen, T.R.; Vanclay, J.K. The Amazon flood plain forest tree Maquira coriacea (Karsten) C.C. Berg: Aspects of ecology and management. For. Ecol. Manag. 2001, 150, 103-113. [CrossRef]

61. Schöngart, J. Growth-Oriented Logging (GOL): A new concept towards sustainable forest management in Central Amazonian várzea floodplains. For. Ecol. Manag. 2008, 256, 46-58. [CrossRef]

62. Bogino, S.M.; Villalba, R. Radial growth and biological rotation age of Prosopis caldenia Burkart in Central Argentina. J. Arid Environ. 2008, 72, 16-23. [CrossRef]

63. Dorado, M.; Astini, E.; Verzino, G.; Di Rienzo, J.; Perpi, A.E. Growth curves for Pinus elliottii, Pinus taeda and Pinus radiata in two areas of the Calamuchita Valley(Córdoba, Argentina). For. Ecol. Manag. 1997, 95, 173-181. [CrossRef] 
64. Verzino, G.; Ingaramo, P.; Joseau, J.; Astini, E.; Di Rienzo, J.; Dorado, M. Basal area growth curves for Pinus patula in two areas of the Calamuchita Valley, Córdoba, Argentina. For. Ecol. Manag. 1999, 124, 185-192. [CrossRef]

65. Sist, P.; Fimbel, R.; Sheil, D. Towards sustainable management of mixed dipterocarp forests of Southeast Asia: Moving beyond minimum diameter cutting limits. Environ. Conserv. 2003, 30, 364-374. [CrossRef]

66. Brienen, J.W.; Zuidema, P.A. The use of tree rings in tropical forest management: Projecting timber yields of four Bolivian tree species. For. Ecol. Manag. 2006, 226, 256-267. [CrossRef]

67. Yang, Y.S.; Guo, J.F.; Chen, G.S.; Xie, J.S.; Gao, R.; Zhen, L.; Zhao, J. Carbon and nitrogen pools in Chinese fir and evergreen broadleaved forests and changes associated with felling and burning in mid-subtropical China. For. Ecol. Manag. 2005, 216, 216-226. [CrossRef]

68. Yang, M.; Wang, S.L.; Zhang, W.D.; Wang, Q.K. Dynamics of biomass and nutrient accumulation in a Chinese-fir plantation. Chin. J. Appl. Ecol. 2010, 21, 1674-1680. (In Chinese)

69. Yu, Y.F.; Song, T.Q.; Zeng, F.P.; Peng, W.X.; Wen, Y.G.; Huang, C.B.; Wu, Q.B.; Zeng, Z.X.; Yu, Y. Dynamic changes of biomass and its allocation in Cunninghamia lanceolata plantations of different stand ages. Chin. J. Ecol. 2013, 32, 1660-1666. (In Chinese)

70. Wu, J.; Wang, Y.; Yang, Y.; Zhu, T.; Zhu, X. Effects of crop tree release on stand growth and stand structure of Cunninghamia lanceolata plantation. Chin. J. Appl. Ecol. 2015, 26, 340-348. (In Chinese)

71. Passauer, D.P.; Aust, W.M.; Bolding, M.C.; Strahm, B.D.; Burger, J.M.; Patterson, S.C.; Vance, E. Potential above-ground biomass losses from severe soil rutting during wet weather timber harvests of coastal plain loblolly pine (Pinus taeda) plantations mitigated by mechanical site preparation. For. Ecol. Manag. 2013, 307, 266-273. [CrossRef]

72. Fox, T.R.; Kyle, K.H.; Andrews, L.J.; Aust, W.M.; Burger, J.A.; Hansen, G.H. Long-term effects of drainage, bedding, and fertilization on growth of loblolly pine (Pinus taeda L.) in the coastal plain of Virginia. South. J. Appl. For. 2005, 29, 205-214.

(C) 2016 by the authors; licensee MDPI, Basel, Switzerland. This article is an open access article distributed under the terms and conditions of the Creative Commons Attribution (CC-BY) license (http:/ / creativecommons.org/licenses/by/4.0/). 